\title{
ESCOLA BRASILEIRA: O PROJETO DE EDUCAÇÃO MORAL PARA A MOCIDADE EM JOSÉ DA SILVA LISBOA, O VISCONDE DE CAIRU (1756-1835)
}

\author{
Dalvit Greiner de Paula* \\ lattes.cnpq.br/2917223669460847 \\ Vera Lúcia Nogueira** \\ lattes.cnpq.br/3537916564986264
}

\begin{abstract}
Resumo: Esta comunicação é resultante de pesquisa cujo objetivo era investigar o projeto de educação moral ofertado por José da Silva Lisboa, o visconde de Cairu (1756-1835) por meio de seu livro Escola Brasileira ou Instrucção Útil a todas as classes junto com a Lei das Escolas de Primeiras Letras, ambos de 1827, no Brasil. Silva Lisboa é um homem do Antigo Regime em fase de transição para um mundo moderno. Formou-se professor e magistrado na ilustração coimbrã e exerceu vários cargos na administração colonial e imperial. Arregimentado por D. João VI em 1808 fez da sua vida na Corte constante defesa do trono e do altar. Analisando seus livros e sua vida parlamentar vimos que sua participação no processo de construção das instituições brasileiras, com a criação de um modelo educacional, tornou-se parte natural de seu projeto intelectual. Refutando tudo aquilo que não devia se consolidar, por que trazia o sinal da barbárie, e conservando tudo aquilo que trazia os traços demonstrativos da civilização, dedicou-se à escrita de livros destinados à formação moral do cidadão brasileiro tendo como princípios a Fé, a Liberdade e a Ordem, mesclando um pensamento e uma linguagem liberal e conservadora.
\end{abstract}

Palavras-chave: Educação liberal; Educação moral; Escola Brasileira; Visconde de Cairu; Primeiro Império.

\section{BRAZILIAN SCHOOL: THE PROJECT OF MORAL EDUCATION FOR YOUTH IN JOSÉ DA SILVA LISBOA, THE VISCOUNT OF CAIRU (1756-1835)}

\footnotetext{
* Doutorando em Educação pela Universidade Federal de Minas Gerais, UFMG (Brasil). Contato: dalvit.greiner@gmail.com.

** Doutora em Educação. Docente da Universidade do Estado de Minas Gerais, UEMG (Brasil). Contato: vlnogueira@gmail.com.
} 
Abstract: This article is the result of a research whose objective was to investigate the project of moral education offered by José da Silva Lisboa, the viscount of Cairu (1756-1835) through his book Escola Brasileira ou Instrucção Útil a todas as classes along with Law of the Schools of First Letters, both of 1827, in Brazil. Silva Lisboa is a man of the Ancient Regime in phase of transition to a modern world. He trained as a teacher and magistrate in the Coimbra University illustration and held various positions in colonial and imperial administration. Arranged by King John VI in 1808 made his life in the Court constant defense of the throne and altar. Analyzing his books and his parliamentary life we saw that his participation in the process of building Brazilian institutions, with the creation of an educational model, became a natural part of his intellectual project. Refuting everything that should not consolidate, because it bore the sign of barbarism, and preserving everything that bore the demonstrative traits of civilization, he devoted himself to the writing of books destined to the moral formation of the Brazilian citizen, having as principles the Faith, the Liberty and the Order, mixing liberal and conservative thinking and language.

Keywords: Liberal education; Moral education; Brazilian School; Viscount of Cairu; First Empire.

\section{Introdução}

Esse artigo está dividido em três partes e uma conclusão. Nele apresentamos o resultado de nossa pesquisa de mestrado em Educação que teve como objetivo investigar o ideário educacional e moral de José da Silva Lisboa (1756-1835), o visconde de Cairu, exposto à sociedade brasileira da primeira metade do século XIX por meio do seu livro Escola Brasileira ou Instrucção Útil a todas as classes. A pesquisa foi desenvolvida no Programa de Pós-graduação em Educação da Universidade Estadual de Minas Gerais na área de concentração em História da Educação.

Na primeira parte, desenvolvemos uma exploração na tentativa de localizar o objeto da pesquisa em seu tempo e lugar, selecionando as fontes primárias necessárias ao nosso entendimento em arquivos, bibliotecas, sítios virtuais, etc., rastreando a historiografia para uma 
análise das fontes secundárias. Para tal, apoiamo-nos no referencial teórico-metodológico da História Cultural. Nossa pretensão, a partir de buscas na Hemeroteca Digital da Biblioteca Nacional no Rio de Janeiro, nas leituras de suas biografias já publicadas, foi o de traçar a trajetória de Silva Lisboa e um panorama de sua época quanto ao discurso e o fazer da educação. Reconstruímos os seus discursos sobre a educação na tentativa de apreender a concepção de educação moral subjacente ao seu projeto.

Na segunda parte, descrevemos a articulação entre a sua atividade intelectual e a educação nacional exposta nas discussões para a Constituição do Estado e de instituição da educação com a publicação da Lei das Escolas de Primeiras Letras em 1827. Tentamos, dessa forma, verticalizar a ação e os efeitos provocados pelo nosso objeto ao longo do tempo e no diálogo com outras produções daquele momento na tentativa de captar "o simbólico e suas representações" (BURKE, 2005, p. 10), para traçarmos um estudo sobre "o conjunto das formas de pensamento" (CHARTIER, 2002, p. 31). Sabendo que a História da Educação "entendida aqui enquanto um campo de investigações [com] seus diferentes objetos" (VEIGA, 2003, p. 19), buscamos identificar nas obras do visconde de Cairu a materialização de sua ação política e intelectual e a sua vontade pedagógica de servir às novas gerações. Um primeiro sintoma do desejo de legar algo para a construção da nação é a similaridade nos títulos: Constituição do Império e Constituição Moral. A hipótese que buscamos comprovar é a de que o visconde de Cairu acreditava que a primeira conforma o Estado, a segunda conforma o povo, a nação que está nascendo.

Por fim, na terceira parte analisamos a obra Escola brasileira ou instrucção util a todas as classes exthraida da Sagrada Escriptura para uso da mocidade - Volumes I e II, publicada em 1827, de modo a entender o livro dentro do projeto civilizacional do visconde de Cairu identificando ali as bases para o edifício moral proposto. Ali, também é possível perceber que há uma recorrência de conceitos tais como Civilização, Educação, Indústria, Mestre, Professor que em seu conjunto 
representam quase quinhentas entradas. Consideramos ser estas as palavras fortes do livro.

Ao final, a parte conclusiva, tentamos responder à questão da nossa proposta de pesquisa: que traços nos constituem a partir do nosso surgimento como nação independente - o Brasil em 1822 - e que consolidaram, por intermédio das leis e normas, a nossa moral social? Concluímos que: a) Silva Lisboa é um homem da transição do Antigo Regime, projetando-se num Brasil moderno; b) é um homem das letras e a letra é sinal de vida, pois sem elas caminhamos, às cegas, para a barbárie em todos os sentidos; c) é um homem da Corte que visa civilizar todas as classes nos preceitos do liberalismo e da moral cristã. Tendo como base a Fé, a Liberdade e a Ordem, Silva Lisboa organiza um projeto racional inspirado na Fé da qual deriva a Liberdade construída na lei que tem por objetivo final a restauração e manutenção da Ordem (doméstica, social, universal). O que tentamos buscar neste trabalho são os "mecanismos através dos quais categorias de pensamentos fundamentais se tornam, num dado grupo de agentes sociais, esquemas interiorizados e não algo que sobre-estrutura todos os pensamentos ou ações particulares" (CHARTIER, 2002, p. 39).

\section{Um mundo em transição: um homem da transição}

Buscando conhecer a obra do visconde de Cairu percebemos em sua biografia a articulação entre a sua atividade intelectual e um projeto de educação nacional destinado à mocidade brasileira e em suas lições identificar o seu ideário moral. Silva Lisboa se apresenta como um homem da Corte e seu projeto educacional visa civilizar todas as classes de cidadãos brasileiros dentro dos preceitos do liberalismo e da moral cristã. Sua visão liberal é demonstrada na sua argumentação em que defende uma abertura aos talentos e virtudes de cada um, seja o indivíduo na sociedade ou às nações no mercado mundial. A questão de 
fundo é que dentro de um modelo liberal é concedido total liberdade para que esse indivíduo desenvolva os seus talentos e suas virtudes. Porém, numa visão de Estado mínimo, não é dever desse mesmo Estado ofertar e manter a educação.

José da Silva Lisboa é um homem do Antigo Regime em fase de transição para um mundo moderno. É um homem de seu tempo. Liberal, afeto às Luzes institucionalizada pelos reformadores e professores da Universidade de Coimbra, Silva Lisboa não se configura, à primeira vista, como uma contradição. Está em perfeita sincronia com seu mundo. A sua participação no processo de construção das instituições brasileiras, passando por um modelo educacional, torna-se parte natural de seu projeto intelectual. Preparado na filosofia racional-liberal anterior à Viradeira, principalmente no campo do Direito, apresenta-se como alguém capaz de entender e explicar o seu tempo e o seu lugar - tanto social quanto político. Dá-se o nome de Viradeira à atuação política regressista da rainha D. Maria I, sucessora de D. José I, que começou com a demissão do Marquês de Pombal, primeiro-ministro sob o qual se fez as reformas educacionais em Portugal, nas colônias e, principalmente na Universidade de Coimbra. A política de desmantelamento atingiu em cheio a universidade e "enquanto Pombal é associado às Luzes e aos progressos científicos, sobretudo das ciências naturais, a soberana é vinculada à ignorância, ao fanatismo religioso, à superstição, ao atraso socioeconômico e ao refluxo das ciências em Coimbra" (VILLALTA, 2011, p. 186).

Dessa maneira, refutou tudo aquilo que não devia se consolidar, pois trazia o sinal da barbárie; conservou tudo aquilo que trazia os traços demonstrativos da civilização. Criou, assim uma linguagem própria. Isso lhe permitiu juntar ao mesmo tempo sinais e marcas do Antigo Regime português e um novo vocabulário e repertório moderno do liberalismo inglês de maneira que a convivência destes signos redundasse numa nova ideia de civilização. Uma contradição? Não, mas, a necessária adequação do conceito de liberdade capitalista ao conceito de liberdade política proposto pelos liberais, postos em prática pelas monarquias constitu- 
cionais, seja no modelo inglês ou na França da Restauração (1815-1830). Numa palavra: conservador.

Hobsbawm (1982), no seu clássico A Era das Revoluções, alertanos que no período que se seguiu à Revolução Francesa até a Comuna de Paris em 1848 gerou-se uma tendência à secularização da vida e da política provocada por uma tentativa de instalação de um modelo estatal laico e democrático. Isso não impediu a permanência, entre os pobres, dos dogmas de fé necessários à manutenção da crença na fé e na Igreja Católica provocando, inclusive, um forte revival religioso carregado de temor e terror. Esse retorno da religiosidade é uma reação àquela laicização provocada pela Revolução Francesa. No seu aspecto religioso presenciamos o surgimento de seitas, messianismos e aparições que reforçam a fé; no seu aspecto político presenciamos uma fixação na figura do bom pastor, a autoridade requisitada para a manutenção da ordem perdida. Esse imaginário do bom pastor é transferido para a política e usado como recurso para atacar toda e qualquer atitude política como resultante da apostasia, da falta de fé que sustenta o homem e a humanidade no rumo de Deus.

No projeto de restauração da Europa, a partir de 1815, da desesperada tentativa de evitar novas revoluções, forçados por uma massa de trabalhadores pobres que teimavam em ocupar seu lugar de importância na produção do mundo reforçados na fé que os impelia a um novo ordenamento, mas com Deus, até mesmo os britânicos perceberam a urgência e a inevitabilidade de reformas temerosos de que uma nova onda implodisse o continente, tão forte tinha sido a propaganda revolucionária. Os europeus aprenderam que na Igreja e no controle e incentivo da religiosidade popular, o retorno de uma ordem divina do mundo eram os melhores suportes para os tronos e dessa forma se apoiaram naqueles que seriam os melhores elos entre um poder espiritual e temporal para não cair no secularismo: os sacerdotes.

Não é à toa que o número de sacerdotes no primeiro parlamento brasileiro é alto. Tanto na Assembleia Constituinte de 1823 quanto na primeira legislatura em 1826 encontramos um número significativo de 
membros do clero: sacerdotes, bispos, irmãos leigos de ordens religiosas. No papel de censores durante o governo de D. João VI, Silva Lisboa vai dividir seus afazeres com dois sacerdotes. Na Comissão de Instrução Pública do Senado, juntos a Silva Lisboa lá estavam mais dois sacerdotes.

Silva Lisboa é um homem de fé. Mas também um homem formado nas Luzes. Como conciliar características aparentemente antagônicas? Fazendo com que a fé encontre a economia e o economista se encontre com o moralista. E o faz lendo os ingleses: Adam Smith, Jeremy Bentham e Edmund Burke. E o faz combatendo os franceses apóstatas encabeçados por Jean-Jacques Rousseau.

Essa recriação original começou a ser desenvolvida ainda em fins do século XVIII com as leituras de Adam Smith pelo professor Silva Lisboa, então Deputado da Junta do Comércio da Bahia em seus primeiros livros publicados em Portugal trazendo para o contexto colonial ideias de um capitalismo em começo de acelerada pulsação. Isso nos dá provas de sua condição exponencial naquele contexto. Mais do que uma adaptação de ideias, uma adequação ao contexto colocado pela necessidade de desconstrução do exclusivo colonial sem perder as vantagens do centralismo autoritário na figura do rei. Essa fase de transição já estava posta pelas reformas promovidas por D. Rodrigo de Souza Coutinho que com sua ilustração reeditava, sob novas circunstâncias, o ideário pombalino de reestruturação da Coroa visando a sua manutenção diante de um mundo em convulsão. A continuação da obra de Pombal, adaptada por D. Rodrigo de Souza Coutinho deve ser visto como um modelo reformador racional que olha para o futuro do reino trazendo na sua base as marcas do Antigo Regime português: o clientelismo e as mercês.

A manutenção da máquina mercantil e do patrimônio real - no caso as Colônias - carecia de novos intelectuais produtores de novas mentalidades e novos consensos. Como leitor de Smith e propagador de suas ideias na Colônia, Silva Lisboa está atento aos incômodos sentidos pelos produtores da Bahia ao excesso de legislação proibitiva e inibitiva do comércio com o restante do Atlântico. Ao escrever os Princípios de 
direito mercantil, publicado em 1801, usa de uma linguagem pedagógica demonstrando a compatibilidade entre moral e economia articulando a lógica necessária para o entendimento de que é no comércio e na indústria que se encontra o progresso e a felicidade de uma sociedade e a paz num mundo de trocas e satisfação de necessidades.

Já em 1804, quando publica seus Princípios de economia política, defende abertamente a quebra dos monopólios pois apenas a justeza das trocas proporcionaria a liberdade do comércio e a satisfação das necessidades. Essa liberdade de comércio é o principal fator para a civilização e a felicidade dos povos. Na outra ponta do seu discurso, Silva Lisboa compartilha seu ideário iluminista incluindo no seu projeto civilizador a necessidade imperiosa de instrução da população e da liberdade do trabalho. Desde cedo, como moralista, não intervém na decisão do outro para não cercear-lhe a liberdade e também como economista não pretende desestruturar a produção. Silva Lisboa se posiciona como um antiescravagista, mas nunca será um abolicionista.

A ideia que lhe persegue é a de contenção dos ímpetos e desejos, por meio de uma instrução moral fazendo com que a razão opere de forma a manter os mesmos homens vivos e produtivos. Uma visão hobbesiana do homem e da humanidade sempre perseguiu Silva Lisboa. Ainda em Portugal, estudante em Coimbra, provavelmente ouviu falar de todas as revoluções de seu tempo, da Revolução Americana em 1776, até a Confederação do Equador em 1824, contra o governo de D. Pedro I; sem contar as infindáveis e pequenas revoltas de escravos e do povo pobre do Reino e depois do Império. O mundo estava convulsionado: estávamos na Era das Revoluções (HOBSBAWM, 1982). E, na visão conservadora, as revoluções são o contrário do progresso humano, pois elas não promovem a humanidade e destroem as civilizações, instituindo o reino das paixões e a barbárie. Ou seja, no contexto civilizacional europeu, que Silva Lisboa construía seu ideário, a civilização trazia uma dupla antítese, revolução e barbárie, sendo a segunda uma condição natural ou a resultante da primeira no exercício do poder despótico. $\mathrm{O}$ 
temor dos homens que fizeram o Império do Brasil era de que qualquer levante levasse à barbárie.

Tome-se então que no tempo e no lugar de Silva Lisboa, "miseráveis tempos" (CAIRU, 2001, p. 75), tornou-se o viver um andar sobre corda bamba, limítrofe da fé e da apostasia, da ordem e da desordem, da civilização e da barbárie, da paz civilizada e da violência de nossos desejos e paixões. Em seu projeto de civilização em oposição à barbárie, Silva Lisboa tem na Europa tanto os modelos positivo e negativo. A segunda parte das Observações sobre o comércio franco no Brasil, de 1808 (CAIRU, 2001, p. 75-118) é dedicada a mostrar as vantagens do comércio exercitado pela Inglaterra e as desgraças provocadas pela revolução na França.

Confesso admirador da Grã-Bretanha e de sua riqueza material e moral, Silva Lisboa faz da mesma e de seus autores a sustentação intelectual e moral de seu projeto. Em sua bibliografia não faltarão elogios, citações, traduções de Adam Smith, James Millar, Jeremy Bentham, Edmund Burke e muitos outros ingleses do seu e de outros tempos. A Grã-Bretanha e seu ideário liberal e mercantil serviram para civilizar o mundo conhecido e aqueles países que aquela sujeita, na sua opinião, tem atingido tal grau de civilização e reduzido a sua barbárie. No continente europeu quem conseguiu conter os desatinos dos franceses, senão os ingleses?

No outro extremo, o modelo negativo refletido na desordem e na guerra da França contra o restante do continente, desestruturando a produção e o comércio. É mal visto por Silva Lisboa o espalhamento dos ideais franceses, principalmente a ideia democrática de poder popular que leva todos ao delírio da igualdade. Para Silva Lisboa esse delírio representava a desordem da produção e a miséria econômica da população. Em suas argumentações e demonstrações lembra a todos que tudo se perdeu onde as ideias francesas passaram, inclusive a França. Dessa maneira afirma, que "a nação francesa sempre foi belicosa e a guerra tem sido o seu principal negócio” (CAIRU, 1827a, p. 109) para concluir que "o horrível monstro do fanatismo revolucionário, com todo 
o prestígio dos seus mágicos termos de liberdade e igualdade" (CAIRU, 1827a, p. 93) tem espalhado o terror por todo o mundo.

Como um homem de seu tempo, Silva Lisboa reflete as correntes de pensamento daquela virada de século, seja por adesão ou repulsão. Sua opção já havia sido delineada em seus escritos de fins do século XVIII: fé na religião católica, livre comércio, manutenção da ordem. É este tripé que vai consolidar o projeto conservador da Geração de 1790 que acompanhou D. João VI ao Brasil, e mais tarde, de luzias e saquaremas. Para Silva Lisboa, era necessária uma Constituição. Mas, que fosse digna do rei, assim como a quis o rei, assim como foi. Neste momento, surge o intelectual conservador avesso a qualquer movimentação da sociedade revolucionária ou não, justa ou não - capaz de construir uma retórica religiosa de pavor e medo para convencer seus leitores da necessidade da ordem e do trabalho como condições para a felicidade. A elite brasileira encontrou o seu ideólogo.

A elite proprietária da máquina mercantil quis-se inserida no nascente capitalismo global, mas que ainda mantinha forte espírito conservador característico das economias agrárias monocultoras, percebeu as necessidades de mudanças para a sua manutenção na nova ordem que se instalava. Dessa maneira, construiu-se um ideário de medo e pavor, preso a uma religiosidade tradicional gerando um liberalismo imobilizante e conservador com um viés econômico e social moderados, com a elite avançando politicamente e freando qualquer avanço das classes mais pobres.

De acordo com Aristóteles, o limite do homem é o outro e a morte. Com forte carga emotiva, o conservador acredita ter pleno conhecimento desses limites e percebe que ali, nessa finitude humana encontra-se uma condição necessária ao poder: a coação física ou moral, força ou educação como instrumentos da política. Defendendo um sistema político forte e centralizado, a lei se torna em "tabu intangível, como instrumento primário de estabilização dos processos sociais” (BONAZZI, 1998, p. 245). Dessa forma, qualquer mudança deveria e seria engendrada pelo 
alto, iluminada e conduzida por uma classe de homens que se consideravam portadores das luzes e guias necessários à nação.

$\mathrm{O}$ intelectual do justo meio e da justa razão agiu e pensou todo o tempo na manutenção da ordem numa sociedade que precisava ser educada para atingir a civilização. Porém, enquanto não atingisse as luzes necessárias e o controle de seus apetites e paixões, deveria ser governada com mão forte do pai protetor, com o cajado do bom pastor. A educação será a mola mestra, porém, também com seus limites. As obras de Silva Lisboa mostravam a viabilidade dessa política conservadora de reformas inspiradas por uma cultura bacharelesca emanada de um sistema educacional construído pelo alto sob a batuta das Faculdades de Direito de São Paulo e Olinda.

Silva Lisboa sempre esteve ligado à educação, ao processo civilizatório brasileiro na medida em que acreditava que somente as Luzes levaria os homens à verdadeira civilização. Já no fim da vida, apesar de não deixar de usar a pena para defender o Estado e seu Rei, a Constituição e as instituições dela derivadas, começa a se dedicar a uma escrita cada vez mais pedagógica, no sentido mesmo de instruir a sociedade a partir de sua menor célula: a família. É à família brasileira que o visconde de Cairu vai dedicar seus últimos livros.

\section{O pensamento de Silva Lisboa: vida sem letras é morte}

Ao identificar a participação do visconde de Cairu no processo de institucionalização da educação brasileira em seu fazer intelectual, nos debates públicos, nos jornais e panfletos e em sua ação legislativa durante a Constituinte de 1823 percebemos que estamos diante de um homem das letras e a letra, em todas as suas formas e funções, pois na sua opinião, é sinal de vida, pois sem elas caminhamos, às cegas, para a barbárie em todos os sentidos. É importante explicar a constituição dos 
vínculos sociais, intelectuais e políticos que deram sustentação a esse possível projeto educacional o que significa perceber suas afiliações tanto à época quanto com o olhar de hoje para situá-lo nos grandes grupos em que situamos os movimentos culturais.

Dentre as afinidades literárias vale notar um retorno aos clássicos, de um período pré-Romântico, também caracterizado por novas ideias e atitudes revolucionárias, que se apresentam na Europa como uma fuga aos incômodos provocados por um capitalismo nascente e a ele se opõe afirmando uma nova moral - a moral burguesa - na busca de um homem racional, ingênuo e moralmente movido por um retorno à natureza em seus princípios mais básicos. No Brasil, esse incômodo também se apresenta na forma de revoltas e rebeliões, mas com um inconformismo que vai do estético ao político - nossos árcades são inconfidentes -, passando não apenas pela adaptação de novos hábitos, novo vocabulário e novas relações políticas. Isso se deu nos jornais, no púlpito, nos lugares de debates públicos.

Silva Lisboa não é um escritor no sentido que aplicamos hoje àqueles que se ajuntavam e se ajuntam em academias literárias, mas encontra-se, no tempo e no estilo, entre os prosadores neoclássicos, com Matias Aires Ramos da Silva de Eça (1705-1770) - que escreveu e viveu na Europa na segunda metade do setecentos - e Francisco Sotero dos Reis (1800-1871), professor e jornalista maranhense. Silva Lisboa é um operário da escrita. Escreve para se justificar, para justificar as atitudes do rei, para expor suas convicções, para defender ideias liberais e econômicas, para realizar - tornar real o país que acredita nascer. Em suma, é um pré-Romântico que trazia um projeto de nação esboçado em todos os lugares e meios que escreveu.

Dessa fase de transição os seus contemporâneos vão construir suas biografias no jornalismo, arriscando alguns textos literários, porém nessa condição pré-revolucionária e tensa não podiam abrir mão das suas intenções públicas nem de romper com uma nascente tradição iluminista. Havemos de considerar que os abalos do período, provocados na política desde a chegada de D. João VI (1808) até a consolidação da 
monarquia (1840) darão outras ocupações aos homens de letras que vão expor suas ideias e seus talentos através dos jornais e muito pouco na literatura.

A oratória encontrava seu lugar no púlpito. A arte, o raciocínio, a palavra mediada e meditada, as belas palavras e as belas letras. Aqui se apresentava um dos mais denodados debatedores com José da Silva Lisboa: Frei Francisco de Mont'Alverne (1784-1859), franco adversário daqueles que buscavam explicar as mudanças pelas quais passavam o Brasil e o mundo de maneira lógica e racional. Mesmo que isso significasse fazer de Deus o "Regedor do Universo", expressão muitas vezes usadas por Silva Lisboa.

Com o ocaso das academias literárias do século XVIII, será nas igrejas que a sociedade da corte vai ouvir os grandes oradores do período dentre eles o já citado Frei Francisco Mont'Alverne e Frei Bento da Trindade que, vindo da Bahia, tornou-se Pregador Régio na Corte. Porém, é na Impressão Régia que esses homens de letras e oradores vão se encontrar buscando no convencimento dos censores as licenças necessárias às suas publicações. Nos Annaes da Imprensa Nacional de Alfredo do Valle Cabral (1881) encontraremos todos aqueles homens com quem Silva Lisboa debateu, discutiu e confrontou suas ideias e seus textos. Era um leitor privilegiado como duplo censor da Imprensa Régia.

Mas, o que incomodou José da Silva Lisboa nessa literatura préromântica que se apresentava na virada dos séculos XVIII e XIX? Ousaríamos responder que era o que o opunha a Mont'Alverne: do racionalismo do economista Silva Lisboa derivaria uma moral racional com viés religioso; em Mont'Alverne a moral religiosa não admite a racionalidade animista dos iluministas pré-românticos como explicadora do mundo. Um exemplo: a mão invisível que para o economista Silva Lisboa é Deus agindo na natureza das relações humanas, para o sacerdote Francisco Mont'Alverne essa mão invisível não pode ser confundida com Deus. É uma heresia.

Na concepção do árcade a humanidade deveria retornar ao modo de vida presente no período clássico greco-romano de beleza e culto à 
natureza, abolindo toda e qualquer outra forma de civilização. A razão deveria, pois, informar os homens daquele modo de vida, bucólico e harmonioso. Um homem voltado e devotado a Deus sem a irracionalidade barroca que tanto o constrangeu em sua humanidade e imperfeição. A felicidade dependerá de um novo modelo de civilização, na medida em que aquela que lá estava não correspondia aos ideais humanos. O retorno a uma vida simples, a uma economia da simplicidade era, naquele tempo, uma atitude revolucionária, pois não era possível negar o atual estágio da civilização, mas era possível reforma-la estética e politicamente. O retorno ao "bom selvagem" de Montaigne na figura dos índios de Basílio da Gama no Uraguai e do Caramuru de Santa Rita Durão. A construção de uma idade de ouro com pleno estado de felicidade era possível se o homem buscasse o bem comum e o progresso reconduzindo o Estado, como desejava o poeta e advogado inconfidente Tomaz Antônio Gonzaga, aos princípios do Direito Natural.

É nesse terreno de transição do neoclassicismo para o romantismo que José da Silva Lisboa encontrará a utilidade pedagógica dos Júbilos da América, da Academia dos Seletos no Rio de Janeiro de meados do setecentos. O texto é péssimo, é má literatura, porém cumpriu com presteza e exatidão a sua função no tempo e no espaço ao prolongar um modelo literário que vai persistir nessa fase de transição: a louvação, o louvaminhas público que encontrou seu eco no ciclo literário de preito ao rei. Porém, essa literatura amadora de baixa qualidade e rigor estético não perde sua importância pois nos diz muito da sua época e de seus homens.

A utilidade pedagógica dos Júbilos da América já tinha sido demonstrada aos adultos quando utilizada na Constituição Moral $e$ Deveres do Cidadão. Para relembrar, a Constituição Moral nos traz um herói fundador branco, cristão e europeu com indefectíveis virtudes expressas em suas Máximas Cristãs, Políticas e Militares. Gomes Freire de Andrade é o modelo de cidadão para o novo Império; as Máximas compostas pelos cidadãos do Rio de Janeiro e comentadas por Silva 
Lisboa eram o modelo didático-pedagógico para a construção desse novo cidadão para aquele Império.

Silva Lisboa inscreve sua seleção bíblica na Escola Brasileira no mesmo formato. Às Máximas Cristãs equivalem a sua Instrução Religiosa, a parte I do livro em que demonstra a necessidade de se atribuir a presença de Deus em todas as ações humanas, principalmente em relação ao conhecimento, atacando a soberba dos racionalistas que colocavam a razão como a explicadora de quase tudo o que víamos e sentíamos; às Máximas Políticas equivalem a sua Instrução Econômica, a parte II do livro onde busca demonstrar que todo o ordenamento político de uma sociedade se dá pela via da economia (oikos, nomos, regras da casa), levando ao pé da letra a etimologia da palavra, que implica nas regras de administração da casa, da concepção, passando pela produção e distribuição das riquezas, o que inclui o poder; por fim, às suas Máximas Militares equivalem a sua Instrução Moral, a parte III do livro em que busca demonstrar que um conjunto de deveres ensinados e aprendidos pela sociedade leva-a à paz e à concórdia com a vigilância necessária para que não degenere novamente.

Silva Lisboa não faz Literatura, sequer literatura menor. Não está preocupado com a qualidade artística de sua escrita, mas com os efeitos que ela pode provocar na organização da Nação e do Estado.

\section{O modelo civilizacional:}

\section{Fé, Liberdade e Ordem}

A sua escrita, como toda e qualquer escrita, deve ser vista e reconhecida a partir de "paradigmas de leitura válidos para uma comunidade de leitores, num momento e num lugar determinados" (CHARTIER, 2002, p. 131). Estamos falando de uma comunidade que padece duplamente em sua inscrição na modernidade: se quer moderna pela constituição do Estado e sequer é moderna na constituição da nação. 
Seus paradigmas ainda estão em construção, chocando-se com visões de mundo fortemente marcadas por três culturas cruzando-se entre si.

Ora, culturalmente a Nação antecede ao Estado. E a Nação se faz independente do Estado a partir de sua língua, de seus bens culturais, de sua visão de mundo, de seus "hábitos intelectuais e morais, [...] que constituem a unidade e a nacionalidade" (MATTOS, 1987, p. 258). Em 1822, não havia nem Brasil, nem brasileiros. Era preciso fazer um e outros. Se era rápido fazer o Estado dando-lhe uma Constituição pelo alto, fazer os brasileiros demandaria muito mais tempo e investimento. Investimento necessário a qualquer Sociedade e Estado que se quer perpetuar, como é de sua vocação.

Para que o Brasil entrasse, de fato, no rol das nações civilizadas cujo modelo europeu era o visível e o aceitável à época, era preciso instruir os brasileiros. Esse era um imperativo que não podia ser negado a um povo que, como afirmou o visconde de Cairu, viveu tanto tempo na escravidão e na escuridão colonial. Segundo Ilmar Rohllof de Mattos (1987) era necessário “instruir 'todas as classes' [...] romper as trevas que caracterizavam o passado colonial [e] com as concepções mágicas a respeito do mundo e da natureza" (MATTOS, 1987, p. 259).

O visconde de Cairu se auto impõe este fardo civilizatório, porém, com ressalvas pois "devem-se temer os perigos e os inconvenientes de huma espécie de servidão, que nos induz a seguir cegamente as pegadas dos que os tem precedido, consultando menos a razão que o costume, regulando-se mais pelo que se faz, do que pelo que se deve fazer" (CAIRU, 1827a, p. X, grifo do autor). Os cuidados com a educação são delicados: ao menor erro corre-se o risco de perpetuar e perder toda uma civilização. Consultar menos a razão significava colocar um freio num modelo de instrução que não buscava suas bases na religião cristã católica e que provocaria um novo modelo de servidão: a igualdade, que engendra a democracia, que permite a licenciosidade, que acaba em anarquia. Por isso torna-se necessário uma guia segura e confiável: as Sagradas Escrituras. Elas são essa guia confiável tanto na política quanto na economia e na moral. Elas revelam a verdadeira liberdade. 
O projeto de modernização do Brasil proposto pelo visconde de Cairu baseava-se na Bíblia não apenas como dogma de fé, mas como manual seguro para o que chamava a Lei da Vida. Ali estão as instruções corretas para o trabalho e a indústria e as regras para a Felicidade. Para o visconde de Cairu são instruções que concorrem para a paz entre os homens e por isso o Estado deve garanti-las. Cabe ao Estado apenas garantir a sua execução começando pelo mínimo de instrução moral e escolar para que o povo, instruído na fé e nas primeiras e divinas letras fortaleça a Autoridade (o Rei) e o Estado.

Para o visconde de Cairu "seria deshonra da Patria o pôr-se em questão, se convem a Geral instrucção do Povo nas Primeiras e Divinas Letras" (CAIRU, 1827a, p. 19-20, grifo do autor). Não se podia desejar nação civilizada sem outra premissa que não fosse a educação do povo. Ao inscrever esse imperativo em sua obra Escola Brasileira, o visconde de Cairu deixa claro a sua defesa para a geral instrução da população, pois acredita que somente ela pode evitar os males pelos quais o Brasil e a Europa vêm passando. Inquestionável e indeclinável. Porém, em sua moral liberal o visconde de Cairu não propõe isso como um direito do povo e um dever do Estado, mas como um imperativo à Sociedade na medida em que crê na educação como um instrumento de autodefesa da sociedade que se eleva em defesa do Estado, não contra o Estado. A saída do estado de barbárie não é do Estado, mas da sociedade. O Estado é a explícita manifestação de uma nação civilizada que já deixou a barbárie pela educação de seus membros.

O Estado tem um fim si mesmo e racionalmente cuida de todos os interesses da sociedade. O visconde de Cairu demonstra que ao contrário do que pensa seus censores apenas a educação retira as pessoas e um país da barbárie. Educar ou não todas as classes não era uma questão a ser discutida. Era preciso discutir como fazê-lo e não se iriam fazê-lo. Naquele momento histórico, o visconde de Cairu acreditava que o Estado já tinha desenvolvido a sua parte. Como um Estado Liberal já não havia nenhuma restrição a que as pessoas se educassem. Por um lado, não havia também nenhuma restrição a quem quisesse abrir escolas, tantas 
quantas cada promotor acreditasse que fosse capaz de manter. O visconde Cairu incentivava esse comportamento na sociedade. Por outro lado, o Estado já havia feito a sua parte ao legislar sobre o assunto autorizando o ensino das Primeiras Letras, instituindo os Cursos Jurídicos, financiando dentro de suas possibilidades todas essas iniciativas do Legislativo brasileiro.

Àqueles que acreditam que a educação das classes ínfimas faria mal à Sociedade e ao Estado, o visconde de Cairu mostra que

As mais especiosas objecções são: $1 .^{\circ}$ que assim como por tal ensino os indivíduos das classes inferiores se habilitão a ler bons livros, também podem ler máos livros, de que já há diluvio em todas as línguas, e que só servem para corruptela e perdição dos leitores: 2. ${ }^{\circ}$ que as pessoas necessárias aos trabalhos mecânicos, adquirindo conhecimentos superficiaes, se desgostão da sua laboriosa condição; e aspirando á mudança de estado, são facilmente seduzidas para Revoluções por insidiosos demagogos (CAIRU, 1827a, p. 19-20, grifo do autor).

O visconde de Cairu é enfático: não é o mau livro que põe a perder a ordem social. É o não leitor que o faz. O mais importante é aprender a ler e escrever. O não leitor não está inscrito no ideário iluminista. O não leitor está sujeito a todas as superstições e crendices que vem assolando o mundo e desestabilizando impérios. O não leitor está mais propenso a aceitar a fala do demagogo na medida em que não exercitou a sua razão nem fortaleceu os seus princípios morais para resistir às tentações que se espalham pelo mundo. Se as pessoas aprendem a ler elas vão ler tudo o que chega até elas. Isso, por si só tem um valor imensurável. Lerão bons e maus livros tantos quantos se lhes apareçam pela frente ou se lhes ponham à mão. A aspiração à mudança de estado social não é o princípio sedutor das Revoluções. Para o visconde de Cairu, as Revoluções acontecem quando todos aspiram à igualdade, princípio que tanto combate em Rousseau, o Sofista de Genebra. O visconde de Cairu provao com dois fatos. O primeiro deles. A Escola teria prevenido a Revolução, pois 
[...] a Revolução da França foi tão extensa e mortífera, pela ignorância, e imoralidade das ínfimas classes ferozes, estimuladas pelo espirito péssimo dos ambiciosos, impostores, charlatães, e semi-doutos do paiz. [...] as classes ínfimas, sendo instruídas nas Primeiras Letras, pódem ler mãos livros; mas já os lerão depois de terem nas Escolas lidos os bons livros (cuja doutrina lhes tenha fortalecido o espirito com princípios sãos) e haverem adquirido o habito do bem, e a vergonha do mal (CAIRU, 1827a, p. 20-21, grifo do autor).

O segundo fato: observou-se na Inglaterra que "a maior parte dos criminosos não sabem ler; e que a causa dos maiores delictos he a incúria que se tem tido na educação do povo, e em o conservar na ignorância das essenciaes doutrinas religiosas" (CAIRU, 1827a, p. 21). Religião e Instrução são as ferramentas de contenção dos pobres.

Há limites nessa instrução? Sim. Para o visconde de Cairu, como vimos no debate sobre a universidade no Brasil, a educação é um investimento e as pessoas que se aplicam a esse bem querem e desejam um retorno. Se todos alçam aos mesmos níveis a sociedade ficará sem trabalhadores mecânicos. Por isso, apenas as primeiras e divinas letras. Portanto, a Constituição que o visconde de Cairu tanto defendia não limitava a ascenção social daqueles que resolvessem explorar suas virtudes e talentos, mas a realidade econômica e o olhar do liberal o impediam de pressionar o Estado visando a geral instrução.

As pessoas não nascem prontas. Torna-se necessário educa-las com valores e princípios que demonstrem o grau da civilização a que pertencem. É preciso "que as pessoas de taes classes sejão industriosas, sóbrias, honestas, fieis, affectuosas, e de consciência em seus negocios diários, pacíficos nas suas maneiras, e aborrecedoras de tumulto e desordem" (CAIRU, 1827a, p. 22-23).

O primeiro entrave que o visconde de Cairu via a um projeto de educação nacional era a escravidão e os maus hábitos que, segundo sua opinião, ela ensejava. Na sua opinião a convivência com os negros em estado de escravidão fazia com que aflorasse nos brancos os mais baixos instintos e perversidades deseducando os meninos e meninas. $\mathrm{O}$ visconde de Cairu e José Bonifácio acreditavam que a educação tiraria os negros 
de sua brutalidade. Porém, enquanto José Bonifácio previa a abolição da escravatura em seu projeto de Brasil, o visconde de Cairu previa a ação da "Mão Onipotente" na resolução desse problema. Ou seja, a mão invisível do mercado deveria, com o tempo e no tempo propício, resolver essa questão.

O cativeiro dá maus exemplos e induz aos mais baixos instintos humanos. Não apenas para os mais novos, mas especialmente para os mais novos. Pedagogicamente, o castigo dos meninos e meninas nas escolas era para o visconde algo deplorável e digno de recomendação que os mestres o evitassem. Como a educação se dá pelo exemplo a escola reproduzia a tirania da relação senhor-escravo. Na sua opinião, o castigo escolar era resultante do modelo de sociedade violenta que vivíamos em função da escravidão, resultando numa educação tirânica pelos "hábitos de violência e soberba dos filhos sobre os seus domésticos" (CAIRU, 1827a, p. 41).

\section{Considerações finais}

A construção de um conceito de Liberdade, explicitada no Capítulo V da Parte III, e que até certo ponto se aproxima de uma liberdade liberal burguesa, vai achar apoio nos versículos bíblicos escolhidos pelo visconde de Cairu. Dessa forma a Liberdade é ensinada aos meninos: "Fallai de tal sorte, e de tal sorte obrai, como quem principia a ser julgado pela Lei da Liberdade - S. Thiago. II, 12" (CAIRU, 1827b, Parte III, p. 88), ou seja, falem e ajam conforme a Lei. Não falem nem construam nada que não possa ser submetido à Lei e aprovado em seu julgamento prévio. A lei é reguladora de todos os contratos, mas principalmente do Contrato Social, e que, portanto, não deve ser corrompida pois confunde e prejudica o seu aprendizado pela sociedade. Sua base moral deve ser sólida para garantir sempre a Liberdade. A incorruptibilidade da Lei garantirá a Liberdade dos cidadãos. E nesse círculo virtuoso, a incorruptibilidade dos cidadãos garantirá a Lei. Por 
isso, os cidadãos devem ser alertados pela educação, na medida em que conhecendo a lei e viver fora das suas prescrições é a mais terrível servidão a que pode se submeter um homem. É o caminho da barbárie.

A Constituição de 1824, nossa primeira e mais duradoura constituição inscreve nossa regra moral por meio da Religião Católica Apostólica Romana, porém com argumentos liberais que consolidou uma tradição autoritária derivando leis que não previam nem desenvolviam a autonomia do cidadão impedindo o crescimento e fortalecimento da esfera pública. A escola pública e oficial, com sua prática e sua pedagogia serviu para a manutenção dessa sociedade.

O verbete Civilizado - Policiado - Polido do Ensaio sobre alguns synonymos da língua portuguesa de 1824, de Frei Francisco de São Luiz, mostra-nos uma hierarquia que vai da barbárie à civilização. Nesta hierarquia o povo policiado é aquele que está mais próximo do bárbaro, mas que deixou este estado na medida em que já adquiriu o hábito da obediência às leis, por medo ou por natural virtude desenvolvida por seus bons costumes; num segundo momento este povo torna-se civilizado pois ali as leis já substituíram os costumes bárbaros e são decididas e executadas por um corpo político entre a sociedade e o Estado; e, por fim, a polidez, estágio em que o povo alcançou a perfeição de suas virtudes, dando-se ao luxo de viver em paz, liberdade e segurança (sine cura, sem preocupação).

Era um sonho. E continua sendo a esperança, mais uma vez, de que cidadãos educados e polidos possam viver em perfeita anarquia, uma vez que ainda vivemos em tempos policiados. 


\section{Referências}

BONAZZI, T. Conservadorismo. In: BOBBIO, N.; MATTEUCCI, N.; PASQUINO, G. (Org.) Dicionário de Política. $5 \cdot^{a}$ ed., v. I. Brasília; São Paulo: Universidade de Brasília; Imprensa Oficial do Estado de São Paulo, 2000, p. 242-246.

BURKE, P. O que é História Cultural. Rio de Janeiro: Jorge Zahar, Editor. 2005.

CHARTIER, R. A História cultural: entre práticas e representações. 2. ${ }^{\text {a }}$ ed. Lisboa: Difel, 2002.

HOBSBAWM, E. J. A Era das Revoluções: Europa 1789-1848. $4 .^{\text {a }}$ ed. Rio de Janeiro: Paz e Terra, 1982.

LISBOA, J. S. L. Escola Brasileira ou instrucção útil á todas as classes extrahida da Sagrada Escriptura para uso da mocidade. Rio de Janeiro: Imperial Typographia de Pedro Plancher-Seignot, 1827a. 2 volumes, v. I, $182 \mathrm{p}$.

. Escola Brasileira ou instrucção útil á todas as classes extrahida da Sagrada Escriptura para uso da mocidade. Rio de Janeiro: Imperial Typographia de Pedro Plancher-Seignot, 1827b. 2 volumes, v. II, 152 p. 34, 2001.

. José da Silva Lisboa, Visconde de Cairu. São Paulo, SP: Editora

MATTOS, I. R. O Tempo Saquarema. São Paulo: Hucitec; Brasília: Instituto Nacional do Livro, 1987.

SÃO LUIZ, F. F. Ensaio sobre alguns synonymos da língua portuguesa. 2. ${ }^{\mathrm{a}}$ ed. Lisboa: Typografia da Academia Real das Sciencias, 1824.

VEIGA, C. G. História Política e História da Educação. In: VEIGA, C. G.; FONSECA, T. N. L. (org.). História e Historiografia da Educação no Brasil, Belo Horizonte: Autêntica, 2003, p. 13-48.

VILLALTA, L. C. A Universidade de Coimbra sob o reformismo ilustrado português (1770-1807). In: FONSECA, T. N. L. (org.) As Reformas Pombalinas no Brasil. Belo Horizonte: Mazza Edições, 2011, p. 157-202.

Recebido em 23 de fevereiro de 2017.

Aprovado em 12 de julho de 2017. 